\title{
Distribution of Cytochromes in Bacteria: Relationship to General Physiology
}

\author{
DAVID J. MEYER ${ }^{\perp}$ and COLIN W. JONES
}

\author{
Department of Biochemistry, The University of Leicester, England
}

\begin{abstract}
A review of cytochrome occurrence in bacteria is presented which gives the taxonomic distribution of cytochromes and which relates this to general physiological characteristics. Data obtained from published research and recent experimental studies on a total of 169 species of bacteria suggested the existence of four major groupings: (i) the aerobic and facultatively anaerobic, heterotrophic gram positives (cytochrome pattern $a a_{3} . o . b . c$ ); (ii) the aerobic and facultatively anaerobic, heterotrophic gram negatives (cytochrome pattern either $a_{1}$.d.o.b.c, $a_{1} . o . b . c$ or $a a_{3} . o . b . c$ ); (iii) anaerobic and microaerophilic heterotrophs (cytochrome pattern $b$ sometimes with $a_{1} / d / o$ ), and (iv) the chemo- and photo-autotrophs (cytochrome pattern $c$ plus $a_{1} / a a_{3} / o / b$ ). The absence or minor presence of cytochrome $c$ in facultatively anaerobic and anaerobic heterotrophs was confirmed and was also observed in plant and animal pathogens. Cytochrome $d$ was confined in occurrence mainly to a small taxonomic group of organisms characterized by a high degree of adaptability to unstable habitats. This group was considered for further subdivision dependent upon the conditions causing the production of cytochrome $d$.
\end{abstract}

As part of an investigation into the occurrence of more than one spectral type of cytochrome oxidase in many bacteria, a survey of published data was carried out. In addition, a number of species were examined experimentally to extend existing data.

In contrast to previous reviews $(14,39,56$, $57,89,90)$, this study constitutes a general approach relating cytochrome composition to the physiology and taxonomy of a large number of bacterial species. Three general observations have been reported: firstly, that the cytochrome pattern $a a_{3} . o . b . c$ occurred predominantly in gram-positive bacteria, and the pattern $a_{1}$.d.o.b.c occurred predominantly in gram-negative species (65); secondly, that cytochrome $c$ was very of ten concluded to be absent from facultatively anaerobic species (42, 65 ); and, thirdly, that cytochromes $a_{1}$ and $d$ always occurred together (86). This investigation evaluates and extends these suggestions.

\section{MATERIALS AND METHODS}

Analysis of published work. The following types of data from relevant scientific publications were assim-

'Present address: Department of Biochemistry, Dartmouth Medical School, Hanover, N.H. 03755. ilated on organisms in the three major bacterial orders: (i) the taxonomic status of the species according to Bergey's Manual of Determinative Bacteriology (13) (i.e., the order, family, genus, species, strain, and response to Gram stain); (ii) the physiological type (e.g., heterotrophic, facultatively anaerobic); (iii) the culture conditions with respect to the terminal electron acceptor, the sources of carbon and nitrogen, and the phase of growth of the culture; and (iv) the qualitative cytochrome content. (Although the seventh edition of Bergey's Manual (1957) is considerably out of date, it was considered to be the most workable classification for the present study.) Where a publication failed to conclude whether an $a$ type cytochrome was $a_{1}$ or $a a_{3}$, the cytochrome was classified for the survey on the basis of the position of its $\alpha$ peak in the reduced minus oxidized spectrum, namely, $a_{1}, 586$ to $596 \mathrm{~nm}$, and $a a_{3}, 598$ to $608 \mathrm{~nm}$.

Experimental studies. Bacteria mainly from taxa not previously investigated were cultured at $30 \mathrm{C}$ in 600-ml batches of nutrient broth (Oxoid, England), 26 $\mathrm{g}$ plus $3 \mathrm{ml}$ of Silicone MS Antifoam Emulsion RD per liter (Hopkins and Williams, England) in 21 tri-baffled flasks. Aeration was by gyratory shaking $(180 \mathrm{rpm}$; oxygen dissolution rate, $144 \mathrm{mmol}$ per liter per $\mathrm{h}$ as measured by a titrimetric procedure [26]).

Cells in either the logarithmic or stationary growth phase were harvested by centrifugation at $4 \mathrm{C}$, homogenized in distilled water, recentrifuged, and resuspended by homogenization in $25 \mathrm{mM}$ sodium phosphate buffer ( $\mathrm{pH} \mathrm{7.4)} \mathrm{to} \mathrm{an} \mathrm{extinction} \mathrm{at} 680 \mathrm{~nm}$ of 50 to 80 . Cell suspensions in $8-$ to $10-\mathrm{ml}$ portions 
were disrupted by sonic treatment at 0 to $4 \mathrm{C}$ by use of an MSE 100-W ultrasonic disintegrator at an amplitude of $7.8 \mu \mathrm{m}$ (peak to peak). In general, $3 \mathrm{~min}$ were required to disrupt gram-negative cells, $5 \mathrm{~min}$ for gram positives. Whole cells and cell-wall material were removed by centrifugation at $7,000 \times g$ for $10 \mathrm{~min}$, and the respiratory membranes were sedimented by further centrifugation at $157,000 \times g$ for 1 to $2 \mathrm{~h}$. The membranes were finally suspended in the same buffer to a protein concentration of 4 to $10 \mathrm{mg} / \mathrm{ml}$ as determined by a modified biuret method (41).

Cytochrome content was determined from dithionite-reduced minus oxidized, and dithionitereduced plus $\mathrm{CO}$ minus dithionite-reduced difference spectra obtained at room temperature by use of a Shimadzu MPS 50-L split-beam recording spectrophotometer. The wavelength accuracy was often checked by use of a filter of known spectrum.

Distilled water was used to make up the growth medium, and glass-distilled, deionized water was used for the preparation and examination of respiratory membranes. Reagents were of analytical grade.

\section{RESULTS}

The data obtained in the present work, plus those gathered from the literature, are summarized in Tables 1 to 4 , which include the sources of data.

General observations. Few of the publications examined contained complete information; the presence or absence of cytochrome $o$ was uncertain in nearly two-thirds of the species due to the omission of a reduced plus CO minus reduced spectrum. Where suitable spectra were obtained, cytochrome $o$ was found to be present in $75 \%$ of the species.

There was, in the majority of cases, a close correlation between the cytochrome content and the taxonomic family.

The absence of a distinct absorption peak(s) or shoulder corresponding to cytochrome $c$ occurred not only in heterotrophic, facultative anaerobes but also in species pathogenic for plants and animals, and in several other heterotrophic species.

Although the quantitative and, to a lesser extent, the qualitative cytochrome content varied with growth conditions in many cases, four groups of physiologically and/or taxonomically related species could be distinguished on the basis of their total cytochrome content, as follows.

Group A. The aerobic and facultatively anaerobic, heterotrophic, gram-positive bacteria of the orders Eubacteriales and Actinomycetales indeed contained predominantly the $a a_{3}$.o.b.c pattern (see Table 1). In some cases either cytochrome $a a_{3}$ or $O$ was absent, and in a few cases (Bacillus megaterium [KM] [14], Micrococcus denitrificans [81], and Bacillus subtilis [D473] - see Table 5) cytochrome $a a_{3}$ predominated during logarithmic growth and cytochrome $o$ was present particularly in the stationary phase of growth.

Certain exceptions to the general pattern occurred: in the family Bacillaceae, cytochrome $a_{1}$ and $d$ were observed "in some cultures" of the unusual insect pathogen $B$. popilliae (71), and cytochrome $a_{1}$ was concluded to be present in B. licheniformis S294 (82), although in another strain of this species the expected cytochrome $a a_{3}$ was present in place of $a_{1}$ (see Table 5). In the Micrococcaceae, M. denitrificans was unusual in its ability to produce a cytochrome $c d$ (nitrite reductase) complex when grown anaerobically with nitrate as terminal acceptor (62). This organism was subsequently transferred to a new genus, Paracoccus Davis (28).

Arthrobacter globiformis NCIB 8602 (family Corynebacteriaceae) appeared to be an excep-

TABLE 1. Cytochrome pattern of aerobic and facultatively anaerobic, gram-positive heterotrophs

\begin{tabular}{|c|c|c|c|c|c|}
\hline $\begin{array}{l}\text { Cytochrome } \\
\text { pattern }\end{array}$ & Order & Family & $\begin{array}{c}\text { No. of } \\
\text { species } \\
\text { in agree- } \\
\text { ment }\end{array}$ & $\begin{array}{c}\text { Excep- } \\
\text { tions }\end{array}$ & Sources of information \\
\hline $\begin{array}{l}a a_{3} . o . b . c . \\
\left(a a_{3} \text { or } o \text { are }\right. \\
\text { sometimes ab- } \\
\text { sent; } c \text { is often } \\
\text { absent) }\end{array}$ & $\begin{array}{l}\text { Actinomycetales } \\
\text { Eubacteriales }\end{array}$ & $\begin{array}{l}\text { Actinoplanaceae } \\
\text { Mycobacteriaceae } \\
\text { Streptomycetaceae } \\
\text { Bacillaceae } \\
\\
\text { Brevibacteriaceae } \\
\text { Corynebacteriaceae } \\
\text { Micrococcaceae }\end{array}$ & $\begin{array}{r}10 \\
6 \\
11 \\
14\end{array}$ & $\begin{array}{l}0 \\
0 \\
0 \\
2\end{array}$ & $\begin{array}{l}\left(31,52,-^{a}\right) \\
(8,34,40,57,62,76) \\
(43,66) \\
\\
(14,17,18,19,29,32,61, \\
\quad 63,65,71,82,83,85,93, \\
\quad 98) \\
\left(-^{a}\right) \\
(42,69,80) \\
(17,35,48,49,56,79,81, \\
85,100,105)\end{array}$ \\
\hline
\end{tabular}

${ }^{a}$-, See Table 5 . 
TABLE 2. Cytochrome patterns of aerobic and facultatively anaerobic, gram-negative heterotrophs (group B)

\begin{tabular}{|c|c|c|c|c|c|}
\hline Cytochrome pattern & Order & Family & $\begin{array}{l}\text { No. of } \\
\text { species } \\
\text { in } \\
\text { agree- } \\
\text { ment }\end{array}$ & $\begin{array}{l}\text { Ex- } \\
\text { cep- } \\
\text { tions }\end{array}$ & $\begin{array}{l}\text { Sources of } \\
\text { information }\end{array}$ \\
\hline $\begin{array}{l}\text { Group B-1: } a_{1} \cdot d \cdot o \cdot b . c . ; \\
c \text { is often absent, } a_{1} \\
\text { and } d \text { are often } \\
\text { present only after } \\
\text { log phase }\end{array}$ & $\begin{array}{l}\text { Pseudomonadales } \\
\text { Eubacteriales }\end{array}$ & $\begin{array}{l}\text { Pseudomonadaceae } \\
\text { Achromobacteraceae } \\
\text { Azotobacteraceae } \\
\text { Brucellaceae } \\
\text { Enterobacteriaceae } \\
\text { Rhizobiaceae }\end{array}$ & $\begin{array}{r}20 \\
1 \\
2 \\
4 \\
11 \\
0\end{array}$ & $\begin{array}{l}1 \\
0 \\
0 \\
0 \\
0 \\
1\end{array}$ & $\begin{array}{l}(7,9,10,46,59,60, \\
\quad 77,85,89,97) \\
(6) \\
(17,27,51,85) \\
\left(36,106,103,{ }^{a}\right) \\
(17,33,37,85) \\
(-a)\end{array}$ \\
\hline Group B-2: $a_{1} . o . b . c$. & Pseudomonadales & $\begin{array}{l}\text { Methanomonadaceae } \\
\text { Pseudomonadaceae } \\
\text { Spirillaceae }\end{array}$ & $\begin{array}{l}2 \\
7 \\
3\end{array}$ & $\begin{array}{l}0 \\
2 \\
0\end{array}$ & $\begin{array}{l}\left(75,-^{a}\right) \\
(17,21,27,72,85) \\
(24,25)\end{array}$ \\
\hline Group B-3: $a a_{\mathrm{s}} . o . b . c$. & $\begin{array}{l}\text { Pseudomonadales } \\
\text { Eubacteriales }\end{array}$ & $\begin{array}{l}\text { Caulobacteraceae } \\
\text { Pseudomonadaceae } \\
\text { Rhizobiaceae }\end{array}$ & $\begin{array}{l}1 \\
4 \\
2\end{array}$ & $\begin{array}{l}0 \\
2 \\
0\end{array}$ & $\begin{array}{l}\left(-^{a}\right) \\
(20,21,22,47,89) \\
(4,5,44)\end{array}$ \\
\hline
\end{tabular}

${ }^{a}-$, See Table 5 .

TABLE 3. Cytochrome pattern of anaerobic and microaerophilic heterotrophs (group C)

\begin{tabular}{|c|c|c|c|c|c|}
\hline Cytochrome pattern & Order & Family & $\begin{array}{c}\text { No. of } \\
\text { species in } \\
\text { agreement }\end{array}$ & Exceptions & $\begin{array}{l}\text { Sources of } \\
\text { information }\end{array}$ \\
\hline $\begin{array}{l}\text { Either no cy tochromes, } \\
\text { or cytochrome } b \\
\text { sometimes also with } \\
a_{1} / d / o \text {. (No } c \\
\text { observed.) }\end{array}$ & Eubacteriales & $\begin{array}{l}\text { Bacillaceae } \text { (Clostridia) } \\
\text { Bacteroidaceae } \\
\text { Lactobacillaceae } \\
\\
\text { Propionibacteriaceae }\end{array}$ & $\begin{array}{r}3 \\
3 \\
13 \\
5\end{array}$ & $\begin{array}{l}0 \\
0 \\
0 \\
0\end{array}$ & $\begin{array}{l}(30) \\
(104) \\
(11,15,30, \\
\quad 107) \\
(88,101)\end{array}$ \\
\hline
\end{tabular}

TABLE 4. Cytochrome pattern of autotrophs (group D)

\begin{tabular}{|c|c|c|c|c|c|}
\hline Cytochrome pattern & Order & Family & $\begin{array}{c}\text { No. of } \\
\text { species in } \\
\text { agreement }\end{array}$ & Exceptions & Sources of information \\
\hline $\begin{array}{l}c, \text { together with } \\
a_{1} / a a_{3} / o / b . \\
\text { (No d.) }\end{array}$ & Pseudomonadales & $\begin{array}{l}\text { Athiorhodaceae } \\
\text { Chlorobacteriaceae } \\
\text { Nitobacteriaceae } \\
\text { Spirillaceae } \\
\text { Thiobacteriaceae } \\
\text { Thiorhodaceae }\end{array}$ & $\begin{array}{l}4 \\
2 \\
3 \\
\\
3 \\
5 \\
1\end{array}$ & $\begin{array}{l}0 \\
0 \\
0 \\
0 \\
0 \\
0\end{array}$ & $\begin{array}{l}(56,58,78,91,102) \\
(39,56) \\
(2,3,45,74,90,95,96) \\
(23,50,73) \\
(1,70,94,99) \\
(68)\end{array}$ \\
\hline
\end{tabular}

tion that proved the rule: the cytochrome pattern of this gram-variable organism was, in the logarithmic phase, that of a typical grampositive, heterotrophic aerobe $\left(a a_{3} . o . b . c\right)$, but after the logarithmic phase, cytochromes $a a_{3}$ and $c$ disappeared and were replaced by cytochromes $a_{1}$ and $d$ to yield the pattern of a typical gram-negative, heterotrophic, facultative anaerobe of subgroup B-2, i.e., $a_{1}$.d.o.b.c (see below and Table 5). Concomitant with this change was the appearance, in mixed chains, of gram-negative as well as the original gram-positive cells. This organism is of further interest since it is the only organism observed to produce four spectrally distinct classes of CO-binding cytochromes.

Group B. The aerobic and facultatively anaerobic, heterotrophic, gram-negative bac- 
teria of the orders Eubacteriales and Pseudomonadales are a group which have been distinguished from bacteria in group $A$ on the basis of the regulation of their citrate synthase enzyme and, hence, their general intermediary metabolism (53). This group could be split into three subgroups on the basis of cytochrome pattern dependent upon the $a$ type cytochrome(s) present (see Table 2). If no $a$ type cytochromes were detected, species were classified according to the usual taxonomic considerations. (It was assumed here that $a$ type cytochromes may well have been produced by these species under suitable conditions of culture.)

As a result of these subdivisions, representatives of only two families appeared in more than one group: the Pseudomonadaceae, the largest family in terms of number of species and one whose taxonomy remains the subject of intensive research, and the Rhizobiaceae, which contains three genera, Agrobacterium, Chromobacterium, and Rhizobium, which are related mainly by the relatively crude criterion of morphological similarity.

Exceptions to these groupings were generally of a minor nature, e.g., the absence of cytochrome $b$ in Pseudomonas testosteroni and $P$. acidivorans (89); the notable exceptions were $P$. riboflavina, which contained cytochromes $a a_{3}$ and $d(7)$, and Chromobacterium violaceum, which contained cytochromes $d$ and $o$ but no $a_{1}$ (see Table 5). The latter feature may be attributable to the physiological production of hydrogen cyanide by this species (16).

The organisms producing cytochrome $d$ merit some additional consideration. They appeared to be divided into the following: facultatively anaerobic species, which produced fairly large amounts of cytochromes $a_{1}$ and $d$ in the late logarithmic or stationary phases of growth (6, 16); aerobic species, which produced only small quantities of cytochromes $a_{1}$ and $d$ in the stationary phase unless cultured under severe oxygen limitation (see Table 5); and species which produced significant amounts of cytochromes $d$ and/or $a_{1}$ mainly when grown anaerobically with nitrate as the terminal electron acceptor $(67,103,108)$. It must be stressed, therefore, that for taxonomic use the cytochrome pattern of these species should be examined under a variety of growth conditions.

Group C. The anaerobic and microaerophilic heterotrophs of the order Eubacteriales (see Table 3) were for a long time thought not to contain cytochromes, but in the last decade cytochromes (always including cytochrome $b$ ) were found to be present in several species (although usually associated with the inclusion of heme in the growth medium). Cytochrome $b$

TABLE 5. Qualitative cytochrome content of bacteria examined experimentally

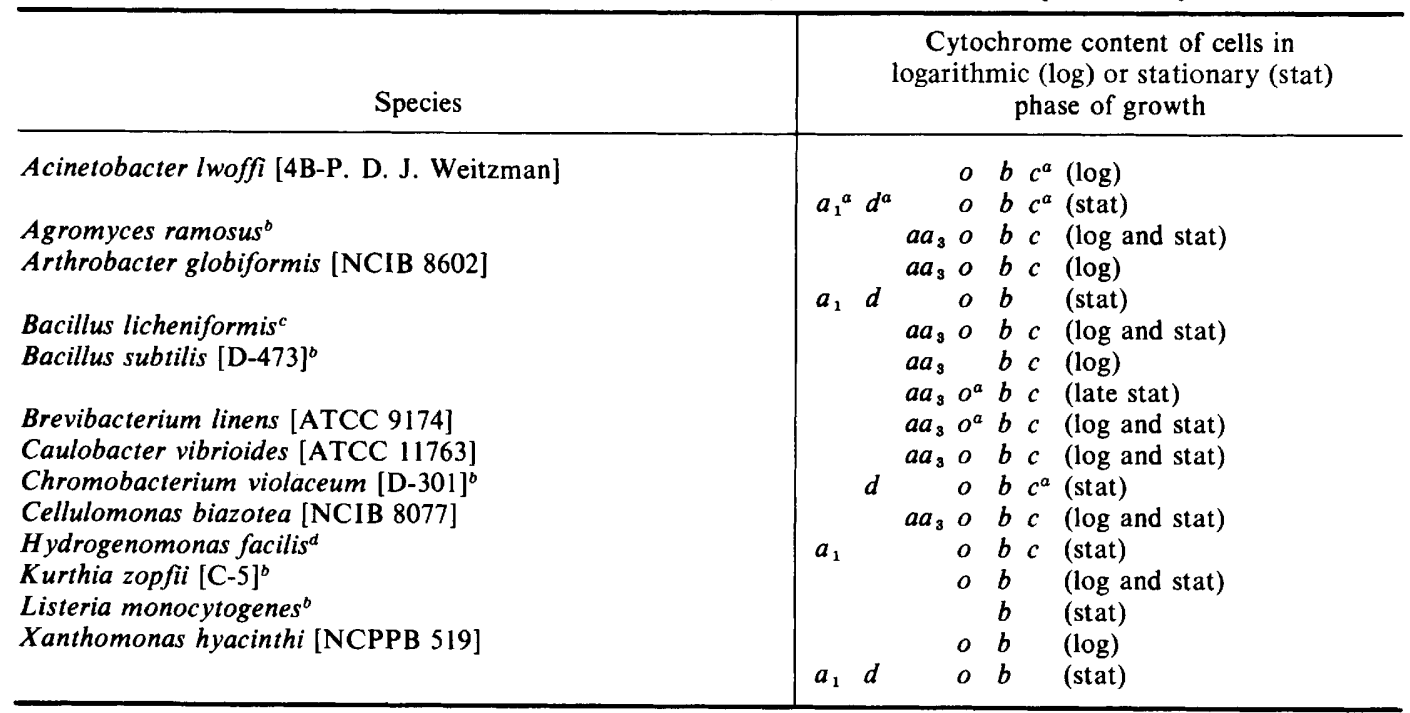

\footnotetext{
${ }^{a}$ Trace amount.

${ }^{b}$ The culture collection of the Medical Research Council's Microbial Systematics Research Unit, University of Leicester, England.

${ }^{c}$ Strain supplied by T. Coultate.

${ }^{d}$ Strain provided by J. Heptinstall.
} 


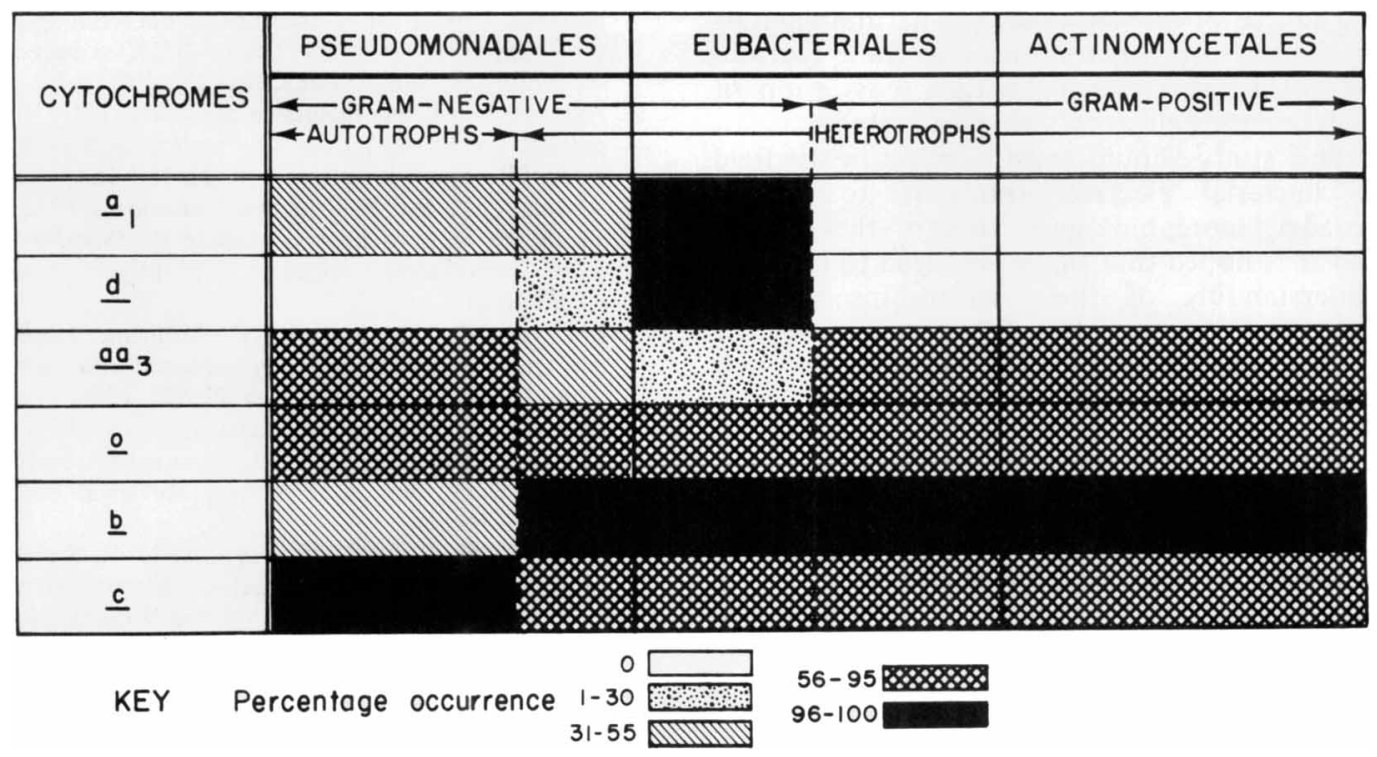

FIG. 1. Distribution of cytochromes in bacteria.

was also found to mediate the anaerobic reduction of fumarate $(88,104)$.

The families Lactobacillaceae and Propionibacteriaceae prompted special interest since the $a$ type cytochromes in these families were $a_{1}$ and $d$ rather than $a a_{3}$ as in other gram positives. This observation suggested a relationship between these species and the gram-negative group B-1 (see above). This relationship could be a direct evolutionary relationship, or it may be connected to their high degree of adaptability (see Discussion). This feature also strongly excludes from the Lactobacillaceae the atypical Microbacterium thermosphactum (at present reservedly classified with the Corynebacteriaceae), which produces cytochromes $a a_{3}$ and $b$ (42).

The only group of bacteria in which the presence of cytochromes has not been detected is the genus Clostridium. Perhaps these organisms have been anaerobes throughout their evolution.

Group D. The chemo- and photo-autotrophs of the order Pseudomonadales (see Table 4) are a complex and diverse group characterized in particular by the omnipresence of cytochrome(s) $c$. The properties of these cytochromes $c$ appear to be quite variable (for review, see references 53,54 ), and it was speculated that these observations could be explained on the basis of cytochrome $c$ having a greater potential for diversification and for evolution as a component in a wide variety of electron transport systems, such as occur in the autotrophic bacteria.

The data presented in Tables 1 to 4 were summarized diagramatically in order to emphasize the taxonomic distribution of each class of cytochrome (see Fig. 1). Note the relatively small taxonomic region in which cytochrome $d$ occurs.

\section{DISCUSSION}

The results obtained with the recent mathematical analysis of Shipp (84) suggest strongly that two or more cytochromes may exhibit only a single absorption peak at room temperature. These findings cast serious doubts on a conclusion that heterotrophic, facultative anaerobes and pathogens lack cytochrome $c$. However, it would seem likely that, although cytochrome $c$ may be present, it is a minor component in these bacteria and must represent a considerable difference in the aerobic oxidation pathway.

The above technique may serve as a refinement to the use of cytochrome composition as a taxonomic characteristic.

It is interesting to speculate that the bacteria (mainly group B-1), which commonly contain three CO-binding cytochromes, are species which are particularly adaptable in unstable environmental conditions, with respect not only to the terminal electron acceptor but also 
the source of carbon; that their natural habitats are highly competitive, and that these features are intimately related to their possession of such complex electron transport systems.

This study should assist workers in the field of bacterial electron transport to take a broader, more biological view of the subject; and it is hoped that this would lead to a greater understanding of the relationships between individual electron transfer systems and the general physiology of the bacteria in their natural habitat.

\section{ACKNOWLEDGMENTS}

Thanks are due to Dorothy Jones for helpful discussions and for providing several bacterial cultures.

D. J. Meyer acknowledges receipt of a Medical Research Council Studentship during the course of this work.

\section{REPRINT REQUESTS}

Address requests for reprints to: Dr. David J. Meyer, Department of Biochemistry, Dartmouth Medical School, Hanover, N.H. 03755.

\section{LITERATURE CITED}

1. Aleem, M. I. H. 1965. Thiosulfate oxidation and electron transport in Thiobacillus novellus. J. Bacteriol. 90:95-101.

2. Aleem, M. I. H., and H. Lees. 1963. Autotrophic enzyme systems. 1. Electron transport systems concerned with hydroxylamine oxidation in Nitrosomonas. Can. J. Biochem. Physiol. 41:763-778.

3. Aleem, M. I. H., and A. Nason. 1959. Nitrite oxidase, a particulate cytochrome electron transport system from Nitrobacter. Biochem. Biophys. Res. Commun. 1:323-327.

4. Appleby, C. A. 1969. The electron transport system of Rhizobium japonicum. I. Haemoprotein $\mathrm{P} 450$, other $\mathrm{CO}$-reactive pigments, cytochromes and oxidases in bacteroids from $\mathrm{N}_{2}$ fixing root nodules. Biochim. Biophys. Acta 172:71-87.

5. Appleby, C. A. 1969. Electron transport system of Rhizobium japonicum. II. Rhizobium haemoglobin, cytochromes and oxidases in free living (cultured) cells. Biochim. Biophys. Acta 172:88-105.

6. Arima, K., and T. Oka. 1964. Cyanide resistance in Achromobacter. I. Induced formation of cytochrome $a_{2}$ and its role in cyanide-resistant respiration. J. Bacterio1. 90:734-743.

7. Arima, K., and T. Oka. 1965. A new combination of cytochromes occurring in Pseudomonas riboflavina. J. Biochem. 58:320-321.

8. Asano, A., and A. F. Brodie. 1964. Oxidative phosphorylation in fractionated bacterial systems. XIV. Respiratory chains of Mycobacterium phlei. J. Biol. Chem. 239:4280-4291.

9. Azoulay, E. 1964. Influence des conditiones de culture sur la respiration de Pseudomonas aeruginosa. Biochim. Biophys. Acta 92:458-464.

10. Azoulay, E., and P. Couchod-Beaumont. 1965. Etude de la cytochrome oxidase de Pseudomonas aeruginosa. Biochim. Biophys. Acta 110:301-311.

11. Baldwin, R. L., and L. P. Milligan. 1964. Electron transport in Peptostreptococcus elsdenii. Biochim. Biophys. Acta 92:421 432 .

12. Bartsch, R. G. 1968. Bacterial cytochromes, p. 181-200. In C. E. Clifton (ed.), Annual review of microbiology, vol. 22. Annual Reviews, Palo Alto, California.

13. Breed, R. S., E. G. D. Murray, and N. R. Smith (ed.). 1957. Bergey's manual of determinative bacteriology, 7 th ed. Williams and Wilkins Co., Baltimore.

14. Broberg, P. L., and L. Smith. 1967. The cytochrome system of Bacillus megaterium KM. The presence and some properties of two CO-binding cytochromes. Biochim. Biophys. Acta 131:479-489.

15. Bryan-Jones, D. G., and R. Whittenbury. 1969. Haematin-dependent oxidative phosphorylation in Streptococcus faecalis. J. Gen. Microbiol. 58:247-260.

16. Brysk, M. M., W. A. Corpe, and L. V. Harkes. 1969. $\beta$-Cyanoalanine formation by Chromobacterium violaceum. J. Bacteriol. 97:322-327.

17. Castor, L. N., and B. Chance. 1959. Photochemical determination of the oxidases of bacteria. J. Biol. Chem. 234:1587-1592.

18. Chaix, P., and P. Flamens. 1953. Pigments hématiniques de Bacillus coagulans cultivé en aérobiose ou en anaérobiose. Biochim. Biophys. Acta 11:530-534.

19. Chaix, P., and G. Roncoli. 1950. A propos de la variabilité du systèmes cytochromes chez certains microorganisms. Biochim. Biophys. Acta 6:268-273.

20. Cheah, K. S. 1969. Properties of electron transport particles from Halobacterium cutirubrum. The respiratory chain system. Biochim. Biophys. Acta 180:320-333.

21. Cheah, K. S. 1970 . The membrane-bound COreactive haemoproteins in the extreme halophiles. Biochim. Biophys. Acta 197:84-86.

22. Cheah, K. S. 1970 . Properties of the membranebound respiratory chain in Halobacterium salinarium. Biochim. Biophys. Acta 216:45-53.

23. Chippaux, M., and M. Pichinoty. 1968. Altération par mutation de la régulation de la biosynthèse des cytochromes par les cultures anaérobies d'une bacterie anaérobie facultative. Eur. J. Biochem. 6:131-134.

24. Clark-Walker, G. D., B. Rittenberg, and J. Lascelles. 1967. Cytochrome synthesis and its regulation in Spirillum itersonii. J. Bacteriol. 94:1648-1655.

25. Cole, J. A., and S. C. Rittenberg. 1971. A comparison of respiratory processes in Spirillum 
volutans, Spirillum itersonii and Spirillum serpens. J. Gen. Microbiol. 69:375-383.

26. Cooper, G. M., G. A. Farnstrom, and S. A. Miller. 1944. Performance of agitated gas-liquid contactors. Ind. Eng. Chem. 36:504-509.

27. Daniel, R. M., and S. K. Erickson. 1969. The effect of glucose on the electron transport systems of the aerobic bacteria Azotobacter vinlandii and Acetobacter suboxidans. Biochim. Biophys. Acta 180:63-67.

28. Davis, D. H., M. Doudoroff, R. Y. Stanier, and M. Mandel. 1969. Proposal to reject the genus Hydrogenomonas: taxonomic implications. Int. J. Syst. Bacteriol. 19:375-390.

29. Doi, R. H., and H. Halvorson. 1961. Comparison of electron transport systems in vegetative cells and spores of Bacillus cereus. J. Bacteriol. $81: 51-58$.

30. Dolin, M. I. 1961. Cy tochrome-independent electron transport enzymes of bacteria, $p$. 428-460. In I. C. Gunsalus and R. Y. Stanier (ed.), The bacteria, vol. 2. Academic Press, New York.

31. Domnas, A., and N. G. Grant. 1970. Cytochrome composition of some members of the Actinoplanaceae. J. Bacteriol. 101:652-653.

32. Downey, R. J., C. E. Georgi, and W. E. Militzer. 1962. Electron transport particles from Bacillus stearothermophilus. J. Bacteriol. 83:1 140-1146.

33. Drabikowska, A. K. 1970. Electron transport system of Salmonella typhimurium cells. Acta Biochim. Pol. 17:89-98.

34. Erickson, S. K. 1971. The respiratory system of the aerobic, $\mathrm{N}_{2}$-fixing, Gram-positive bacterium, Mycobacterium flavum 301. Biochim. Biophys. Acta 245:63-69.

35. Erickson, S. K., and G. L. Parker. 1969. The electron transport system of Micrococcus lutea (Sarcina lutea). Biochim. Biophys. Acta 180:56-62.

36. Fellman, J. H., and R. C. Mills. 1960. The succinoxidase system of Pasteurella tularensis. J. Bacteriol. 79:800-806.

37. Fujita, T. 1966. Studies on soluble cytochromes in the Enterobacteriaceae. I. Detection, purification and properties of $c-552$ in anaerobically grown cells. J. Biochem. (Tokyo) 60:204-215.

38. Gel'man, N. S., M. A. Lukoyanova, and D. N. Ostrovskii. 1967. The respiratory chain of bacteria, p. 71-159. In Respiration and phosphorylation of bacteria. Plenum Press, New York.

39. Gibson, J. 1961. Cytochrome pigments from the green, photosynthetic bacterium Chlorobium thiosulphatophilum. Biochem. J. 79:151-158.

40. Goldman, D. S., M. J. Wagner, T. Oda, and A. L. Shug. 1963. Oxidation of reduced nicotinamide adenine dinucleotide by sub-cellular particles from Mycobaterium tuberculosis. Biochim. Biophys. Acta 73:367-379.

41. Gornall, A. G., C. J. Bardawill, and M. M. David. 1949. Determination of serum proteins by means of the Biuret reaction. J. Biol. Chem. 177:751-766.

42. Hartree, E. F., and C. F. Davidson. 1968.
Cytochrome as a guide to classifying bacteria: taxonomy of Microbacterium thermosphactum. Nature (London) 220:502-504.

43. Heim, A. H., W. S. Silver, and Y. Birk. 1957. Cytochrome composition of some strains of Streptomyces. Nature (London) 180:608-609.

44. Hirata, H., and S. Fukui. 1968. Cytochrome c-552 in Agrobacterium tumefaciens. J. Biochem. 63:780-788.

45. Hooper, A. B., and A. Nason. 1965. Characterization of hydroxylamine-cytochrome reductase in Nitrosomonas europaea and Nitrocystis oceanus. J. Biol. Chem. 240:4044-4057.

46. Hochster, R. H., and C. G. Nozzolillo. 1960. Respiratory carriers and the nature of the reduced diphosphopyridine nucleotide oxidase system in Xanthomonas phaseoli. Can. J. Biochem. Physiol. 38:79-93.

47. Ishaque, M., A. Donawa, and M. I. H. Aleem. 1971. Electron transport and coupled energy generation in Pseudomonas saccharophila. Can. J. Biochem. 49:1175-1182.

48. Jackson, F. L., and V. D. Lawton. 1959. A cytochrome of the $b$ group from Micrococcus lysodeikticus. Biochim. Biophys. Acta 35:76-84.

49. Jacobs, N. J., and S. F. Conti. 1965. Effect of hemin on the formation of the cytochrome system in anaerobically grown Staphylococcus epidermidis. J. Bacteriol. 89:675-679.

50. Jacobs, N. J., and M. J. Wolin. 1963. Electron transport system of Vibrio succinogenes. I. Enzymes and cytochromes. Biochim. Biophys. Acta. 69:18-28.

51. Jones, C. W., and E. R. Redfearn. 1967. The cytochrome system of Azotobacter vinlandii. Biochim. Biophys. Acta 143:340-353.

52. Jones, D., J. Watkins, and D. J. Meyer. 1970. Cy tochrome composition and effect of catalase on growth of Agromyces ramosus. Nature (London) 226:1240-1250.

53. Jones, D., and P. D. J. Weitzman. 1968. Regulation of citrate synthase and microbial taxonomy. Nature (London) 219:270-272.

54. Kamen, M. D., and T. Horio. 1970. Bacterial cy tochromes. I. Structural aspects. p. 673-700. In E. E. Snell (ed.), Annual review of biochemistry, vol. 39. Annual Reviews, Palo Alto, California.

55. Kamen, M. D., and T. Horio. 1970. Bacterial cytochromes. II. Functional aspects, p. 399-428. In C. E. Clifton (ed.), Annual review of microbiology, vol. 24. Annual Reviews, Palo Alto, California.

56. Kamen, M. D., and L. P. Vernon. 1955. Comparative studies on bacterial cytochromes. Biochim. Biophys. Acta 17:10-22.

57. Kearney, E. B., and D. S. Goldman. 1970. Further studies on the NADH oxidase of Mycobacterium tuberculosis. Biochim. Biophys. Acta 197:197-205.

58. Kikuchi, G., Y. Saito, and Y. Motokawa. 1965. On cytochrome oxidase as the terminal oxidase of dark respiration of purple, non-sulfur bacteria. Biochim. Biophys. Acta 94:1-14.

59. Kodama, T., and T. Mori. 1969. A double $c$-ty pe 
cytochrome, $c_{552558}$ of a denitrifying bacterium, Pseudomónas stutzeri. J. Biochem. (Tokyo) 65:621-628.

60. Kodama, T., and S. Shidira. 1969. Components of cy tochrome system and purification and some properties of $c$-type cytochromes of a denitrifying bacterium, Pseudomonas stutzeri. J. Biochem. 65:351-360.

61. Kroger, A., and V. Dadak. 1969. On the role of quinones in bacterial electron transport. The respiratory system of Bacillus megaterium. Eur. J. Biochem. 11:428-440.

62. Kusaka, T., R. Sato, and K. Shoji. 1964. Comparison of cytochromes of mycobacteria grown in vitro and in vivo. J. Bacteriol. 87:1383-1388.

63. McFeters, G. A., D. F. Wilson, and G. A. Strobel. 1970. Cytochromes in a cyanide-resistant strain of Bacillus cereus. Can. J. Microbiol. 16:1221-1226.

64. Matsunaka, S. 1963. The electron transport system of a plant pathogenic bacterium. J. Agric. Chem. Sci. 37:658-667.

65. Miki, K., I. Sekuzu, and K. Okunuki. 1967. The cytochrome system of a strain of Bacillus subtilis. Ann. Rep. Biol. Works Fac. Sci. Osaka Univ. 15:33-60.

66. Niederpruem, D. J., and D. P. Hackett. 1961. Respiratory chain of Streptomyces. J. Bacteriol. $81: 557-563$.

67. Newton, N. 1967. A soluble cytochrome $c a_{2}$ complex from Micrococcus denitrificans, containing nitrite reductase activity. Biochem. J. 105:21C-23C.

68. Newton, N., and M. D. Kamen. 1956. Chromatium cytochrome. Biochim. Biophys. Acta 21:71-80.

69. Pappenheimer, A. M., Jr., J. L. Howland, and P. A. Miller. 1962. Electron transport systems in Corynebacterium diphtheriae. Biochim. Biophys. Acta 64:229-242.

70. Peeters, T., and M. I. H. Aleem. 1970. Oxidation of sulfur compounds and electron transport in Thiobacillus denitrificans. Arch. Mikrobiol. 71:319-330.

71. Pepper, R. E., and R. N. Costilon. 1965. Electron transport in Bacillus popilliae. J. Bacteriol. 89:271-276.

72. Peterson, J. A. 1970. Cytochrome content of two pseudomonads containing mixed function oxidase systems. J. Bacteriol. 103:714-721.

73. Postgate, J. R. 1956. Cytochrome $c_{3}$ and desulphoviridin; pigments of Desulphovibrio desulphuricans. J. Gen. Microbiol. 14:545-572.

74. Rees, M., and A. Nason. 1965. A P450-like cytochrome and a soluble terminal oxidase identified as cytochrome $o$ from Nitrosomonas europaea. Biochem. Biophys. Res. Commun. 21:248-256.

75. Repaske, R. 1966. Characteristics of Hydrogen bacteria. Bacteria. Biotechnol. Bioeng. 8:217-235.

76. Revsin, B., and A. F. Brodie. 1969. Carbon monoxide-binding pigments of Mycobacterium phlei and Escherichia coli. J. Biol. Chem. 244:3101-3104.

77. Sands, D. C., F. H. Gleason, and D. C. Hildebrand. 1967. Cytochromes of Pseudomonas syringae. J. Bacteriol. 94:785-786.

78. Sasaki, T., Y. Motikawa, and G. Kikuchi. 1970. Occurrence of both $a$-type and $c$-type cytochromes as the functional terminal oxidases in Rhodopseudomonas spheroides. Biochim. Biophys. Acta 197:284-291.

79. Sato, R. 1956. The cytochrome system and microbiol reduction of nitrate, p. 163-175. In W. D. McElroy and B. Glass (ed.), Inorganic nitrogen metabolism. The Johns Hopkins Press, Baltimore.

80. Scholes, P. B., and H. K. King. 1965. Electron transport in a Park-Williams strain of Corynebacterium diphtheriae. Biochem. J. 97:754-765.

81. Scholes, P. B., and L. Smith. 1968. Composition and properties of the membrane-bound respiratory chain of Micrococcus denitrificans. Biochim. Biophys. Acta 153:363-375.

82. Schulp, J. A., and A. H. Stouthamer. 1970. Influence of oxygen, glucose and nitrate upon the formation of nitrate reductase and the respiratory system in Bacillus licheniformis. J. Gen. Microbiol. 64:195-203.

83. Seddon, B., and G. H. Fynn. 1971. Terminal oxidations in Bacillus brevis. II. The electron transport system of Bacillus brevis. Arch. Mikrobiol. 77:252-261.

84. Shipp, W. S. 1972. Absorption bands of multiple $b$ and $c$-type cytochromes in bacteria detected by numerical analysis of absorption spectra. Arch. Biochem. Biophys. 150:482-488.

85. Smith, L. 1954. Bacterial cytochromes. Difference spectra. Arch. Biochem. Biophys. 50:299-314.

86. Smith, L. 1961. Cytochromes in aerobic electron transport, p. 365-396. In I. C. Gunsalus and R. Y. Stanier (ed.), The bacteria, vol. 2. Academic Press Inc., New York.

87. Smith, L. 1968. The respiratory chain of bacteria, p. 55-122. In T. P. Singer (ed.), Biological oxidations. Interscience Publishers Inc., New York.

88. Sone, N. 1972. The redox reactions in propionic acid fermentation. I. Occurrence of an electron transport system in Propionibacterium arabinosum. J. Biochem. 71:931-940.

89. Stanier, R. Y., N. J. Palleroni, and M. Doudoroff. 1966. The aerobic pseudomonads: a taxonomic study. J. Gen. Microbiol. 43:159-271.

90. Straat, P. A., and A. Nason. 1965. Characterization of a nitrate reductase from the chemoautotroph Nitrobacter agilis. J. Biol. Chem. 240:1412-1426.

91. Taniguchi, S., and M. D. Kamen. 1965. The oxidase system of heterotrophically grown Rhodospirillum rubrum. Biochim. Biophys. Acta 96:395-428.

92. Tissieres, A. 1951. A study of the cytochrome system and some other aspects of the respiration 
of Aerobacter aerogenes. Biochem. J. 50:279-288.

93. Tochikubo, K. 1971. Changes in the terminal respiratory chain of Bacillus subtilis during germination, outgrowth and vegetative growth. J. Bacteriol. 108:652-661.

94. Trudinger, P. A. 1961. Thiosulfate oxidation and cytochromes in Thiobacillus X. I. Fractionation of bacterial extracts and properties of cytochromes. Biochem. J. 78:673-680.

95. Tsein, H. C., and H. Laudelout. 1971. Changes in cytochrome content and turnover number during growth of Nitrobacter. Arch. Microbiol. 75:266-268.

96. Van Gool, A., and H. Laudelout. 1966. The mechanism of nitrite oxidation by Nitrobacter winogradskyi. Biochim. Biophys. Acta 113:41-50.

97. Vernon, L. P. 1956. Bacterial cytochromes. I. Cytochrome composition of Micrococcus denitrificans and Pseudomonas denitrificans. J. Biol. Chem. 222:1035-1049.

98. Vernon, L. P., and J. H. Mangum. 1960. Cytochromes of Bacillus megaterium and Bacillus subtilis. Arch. Biochem. Biophys. 90:103-104.

99. Vernon, L. P., J. H. Mangum, J. V. Beck, and F. H. Shafia. 1960. Studies on a ferrous-ion oxidizing bacterium. II. Cytochrome composition. Arch. Biochem. Biophys. 88:227-231.

100. Vernon, L. P., and F. G. White. 1957. Terminal oxidases of Micrococcus denitrificans. Biochim. Biophys. Acta 25:321-328.

101. de Vries, W., W. M. C. van Wijk-Kapteiju, and A. H. Stouthamer. 1972. Influence of oxygen on growth, cytochrome synthesis and fermentation pattern in propionic acid bacteria. J. Gen. Microbiol. 71:514-524.

102. Whale, F. R., and O. T. Jones. 1970. The cytochrome system of heterotrophically grown Rhodopseudomonas spheroides. Biochim. Biophys. Acta 223:146-157.

103. White, D. C. 1962 . Cy tochrome and catalase patterns during growth of Haemophilus parainfluenzae. J. Bacteriol. 83:851-859.

104. White, D. C., M. P. Bryant, and D. R. Caldwell. 1962. Cytochrome-linked fermentation in Bacteriodes ruminicola. J. Bacteriol. 84:822-888.

105. White, D. C., and F. E. Frerman. 1967. Membrane lipid changes during formation of a functional electron transport system in Staphylococcus aureus. J. Bacteriol. 94:1868-1874.

106. Whittaker, P. A. 1967. The electron transport system of organism NCIB 8250 (Moraxella sp.). Biochem. J. 103:50P-51P.

107. Whittenbury, R. 1964. Hydrogen peroxide formation and catalase activity in the lactic acid bacteria. J. Gen. Microbiol. 35:13-26.

108. Yamanaka, T. 1964. Identity of Pseudomonas cytochrome oxidase with Pseudomonas nitrite reductase. Nature (London) 204:253-255. 